\title{
Utilization of Pangasius Mince in the Development of Ready to Eat Snacks and its Storage Study
}

\author{
Hina Alim², Shardul Gangan ${ }^{3}$, Quraishi Firdaus Mukhtar² and A.K. Balange ${ }^{1^{*}}$ \\ ${ }^{1}$ Post-Harvest Technology Department, ICAR-Central Institute of Fisheries Education, \\ Mumbai-61, India \\ ${ }^{2}$ Department of Life Sciences, University of Mumbai, Vidyanagari Campus, Santacruz (E), \\ Mumbai-98, India \\ ${ }^{3}$ Taraporevala Marine Biological Research Station, 3rd Floor, New Administrative Building, \\ Govt. Colony, Bandra (East), Mumbai, India \\ *Corresponding author
}

\begin{tabular}{|l|}
\hline Ke y w or d s \\
Pangasius, Mince, \\
Value added product, \\
Sev, Shelf life study, \\
Room temperature \\
\hline Article Info \\
\hline Accepted: \\
18 September 2018 \\
Available Online: \\
10 October 2018 \\
\hline
\end{tabular}

\section{A B S T R A C T}

The demand for ready to eat and ready to cook products are gradually increasing because of their convenience. Considering the demand for ready to eat fish products especially in developing countries like India, there is an instant need to diversify our fish based products. Pangasius is a candidate species for inland aquaculture but the yellow discoloration problem in its fillet has restricted its production recently. Therefore, an attempt has been made in the present investigation to utilize Pangasius mince for making a ready to eat snacks product i.e. fish $\mathrm{Sev}$ and its storage study at room temperature. The results suggested that the fish mince quantity can be kept around 50\% of the total composition. This not only helped in maintaining the textural properties of sev but also improved the nutritional quality and overall acceptability. The storage stability of fish Sev at room temperature was assessed based on the changes in proximate composition, quality indices and sensory analysis of the fish $\operatorname{Sev}$ during 90 days of storage at room temperature. From the results, it was observed that freshly prepared fish $\mathrm{Sev}$ had moisture, protein, fat, ash and carbohydrate as $1.89 \%, 13.89 \%, 24.58 \%, 3.40 \%$ and $56.24 \%$ respectively at day 0 . It was observed that the protein content of the product decreased slightly from $13.89 \%$ to $13.37 \%$ during 90 days of storage. However, moisture content was increased and fat content was decreased gradually at the end of 90 days storage. Lipid oxidation products like peroxide and TBARS values increased gradually but found within acceptable limit at the end of 90 days and $\mathrm{pH}$ value reduced significantly. The product prepared was found acceptable up to 90 days of storage at room temperature based on the sensory evaluation by the trained panelists.

\section{Introduction}

Value addition in general means adding value to the low cost raw material by any means of processing which changes the overall appearance and quality of the product resulting in increased consumer acceptability and price of the final product which can 
benefit both producers as well as consumer. Looking at the present world scenario where both men and women are working for their livelihood and hardly gets time to cook the food, such ready to eat value added products is now becoming one of the best options. Several meat based and starch based value added products are available in the market. However fish based value added products are very less in the Indian market (Hina et al., 2017). Fish is considered as one of the best sources for good quality proteins and health beneficial poly unsaturated fatty acids i.e. EPA and DHA along with other minerals and fat soluble vitamins. Therefore fish based value added products will not only provide an alternative to plant based proteins but also provide essential fatty acids which increase the nutritional value of the end product. There are several fish species available in the local markets of India which fetches very good price in the fresh form and has an established market. However there are some fish species which has very high production potential but fetches less price in the market and categorized as low cost fish. Such low cost fish, which has equally good protein and fat content as high priced fish, can be utilized for value addition which will benefit both fish farmers as well as consumers.

Pangasianodon hypophthalmus, an exotic catfish that is endemic to the waters of Mekong basin in south-east Asia, belongs to the family Pangasiidae and commonly known as river or silver stripped cat fish, sutchi catfish and iridescent shark. Total Pangasius production in India during 2014-15 was 3.63 million MT (FAO, 2014). Pangasiusis being cultured, mainly in the Krishna, West Godavari, East Godavari, Guntur and Nellore districts of Andhra Pradesh. Pangasius farming in Andhra Pradesh represents the fastest growth of a single species farming recorded so far in the aquaculture sector of India. Pangasius meat has high nutritive qualities and excellent sensory properties (Praveen et al., 2017). The fish can be filleted easily due to the absence of intra-muscular pin bone. Nevertheless Pangasius has following major problems which has restricted its production

\section{Yellow discoloration of fillets}

India with its current aquaculture potential can compete with the south east Asian countries, but the main factor leading to the less demand of Indian fillet export is the yellow discoloration. The root cause for this yellow discoloration and overall quality loss of cat fish meat is due to the carotenoid content from the food (Lovell, 1998). Literatures also suggest that natural feed of Pangasius also imparts yellow discoloration to the fillet to a large extent.

\section{High fat content}

Fillets are moderately high in fat, mainly saturated fat, a type of fat that can increase cholesterol. Dietary fat is high in calories but it is vital for optimal health, as it helps body to absorb vitamins and aids in proper growth and development. Fillets are relatively high in cholesterol, increases the risk of heart disease. The amount and composition of the fat content will be influenced by the feed used in aquaculture operations (Hassan et al., 2018).

\section{Low price}

Market demand and associated product prices for different Pangasius species reflect consumer preferences. Basa is the preferred imported variety of Pangasius due to mild to sweet flavor, white meat colour and are thinner with a more coarse texture. Consumer preferences are usually influenced by price or intended recipes. Due to above problems Pangasius is less exported from India ((Hassan et al., 2017). 
In the market, there are many kinds of snack products available such as chakli, sev, bhujia etc. These are rich in carbohydrate content with protein content of $12-13 \%$, fat $43-44 \%$ and shelf life is 3-4 months with the price for $100 \mathrm{~g}$ is Rs 40/-. There is no information available on the preparation of fish $\mathrm{Sev}$ from Pangasius mince and its storage study at room temperature. Therefore an attempt has been made in the present investigation to prepare a value added product i.e. fish $\mathrm{Sev}$ with standardized recipe and protocol from Pangasius mince and its storage stability at room temperature. The outcome of this research will help in giving an alternative for utilization of Pangasius in the form of value added product i.e. fish $S e v$ which will help fish farmers across the India in earning additional income.

\section{Materials and Methods}

Pangasius fish was procured from local fish market of Mumbai and brought to the laboratory in iced condition in an insulated container. The fish samples were gutted and washed properly with portable water to make it free from sand and any other impurities and then processed in a meat-bone separator (Baader694, Germany) under chilled condition (Hina et al., 2017). The mince obtained was then packed in polythene pouches and kept in deep freezer $\left(-18^{\circ} \mathrm{C}\right)$ until further use.

\section{Protocol for making fish Sev}

The recipe and protocol for the preparation of dough for extraction of fish $\mathrm{Sev}$ was taken from the earlier work of Hina et al., (2017) in making fish chakli with slight modification. The slightly modified recipe of fish Sev was achieved by varying the composition of different ingredients with mince and the standardized recipe for the same is given in Table 1. The protocol for making fish Sev is almost similar to that of making fish chakli
(Hina et al., 2017) where in the soft dough was prepared by mixing standardized quantities of all the ingredients as mentioned in Table 1. The dough was then given a round shape manually, smeared with oil and fed to a hand operated extruder with a diameter of 10 $\mathrm{mm}$ and fed directly into frying pan containing $1 \mathrm{~L}$ refined oil $\left(175 \pm 5^{\circ} \mathrm{C}\right)$. The product was then fried by gently shaking up to 3 to $5 \mathrm{~min}$ till it turned golden brown. The product was then removed in another perforated tray to drain the excess oil and allowed it to cool at room temperature (Plate 1). For the storage study of 90 days at room temperature, $700 \mathrm{~g}$ of fried Sevwas packed in a $200 \mu$ polyethylene packets. Samples were drawn at 15 days of intervals and analysed for chemical and sensory parameters.

\section{Analyses}

\section{Proximate composition}

Proximate composition was analysed according to AOAC (2005) method. Ash content was determined in muffle furnace (Phoenix, SEM, USA) by weight loss after 5-6 hours of burning at temperature of $600^{\circ} \mathrm{C}$ until white ash was obtained. Total protein content of the sample was analysed by using Kjeldahl method with the help of Pelican, KelpusKES12L VAI/Classic DXVATS apparatus. Fat content was determined by using Sohxlet method using petroleum ether. Carbohydrate content was calculated by subtracting the values of all the above from 100.Moisture content was determined by direct heating method using hot air oven at temperature $100 \pm 5^{\circ} \mathrm{C}$ for $16-18$ hours.

\section{Biochemical analysis}

TBARS value of the sample was determined according to the method described by Tarladgis et al., (1960). TBARS expressed as mg malondialdehyde/ $\mathrm{kg}$ sample was 
calculated by using Spectrophotometric method. Peroxide Value (PV) of stored sample was analyzed by AOAC, (2005) standard method.

\section{Sensory quality evaluation}

To a sensory panel of 10-12 trained members the samples were served in random order in blind trials and were evaluated on an intensity scale ranging from 1 (no intensity) to 9 (maximum intensity) for parameters viz. color, appearance, texture, odour, taste and overall acceptability.

\section{Statistical analysis}

One-way analysis of variance was performed by using the SPSS (version 16.0, Chicago IL USA). Comparison of means was carried out by Duncan's multiple range tests (Steel and Torrie, 1980). All the experiments were carried out in triplicate.

\section{Results and Discussion}

\section{Standardization of recipe for fish sev}

The commercially available sev or bhujia in the market is generally made from starch base material. However when sev is to be prepared from fish mince then it becomes little challenging as fish protein will be added into it which may affect the textural properties of sev, especially the crispiness. Therefore it becomes very important to carefully standardize the amount of fish mince along with other common ingredients to be added into it. Accordingly the different combinations of fish mince and other ingredients were tried and a recipe of fish sev was standardized as mentioned in Table 1. From the table, it can be seen that when fish mince of $1 \mathrm{Kg}$ is added with rice flour $(500 \mathrm{~g})$, Bengal gram flour $(500 \mathrm{~g})$, red chilli powder $(25 \mathrm{~g})$, sodium bicarbonate(10g), salt (25g) and oil (1 lit), it resulted in the preparation of good quality sev (Table 1). The results also suggested that the fish mince quantity can be kept around $50 \%$ of the total composition. This not only helped in maintaining the textural properties of sev but also improved the nutritional quality and overall acceptability. Hina et al., (2017) also reported almost similar composition for the preparation of fish chakli.

\section{Nutritional value of fish $S e v$}

The nutritive value of any product is determined based on the quantity of protein, fat, minerals, vitamins and carbohydrates present in it. The fish sev prepared in the present investigation has $13.89 \%$ protein, $24.58 \%$ fat, $3.40 \%$ ash (minerals and vitamins) and $57.59 \%$ of carbohydrates. Some of the traditionally prepared sev have the protein content in the range of 8 to $10 \%$. However in the present investigation the protein content in sev was higher (13.89\%) due to the addition of fish mince into it. Nevertheless the quantity of fish mince could not be increased beyond $50 \%$ as it made the texture of fish sev more hard.

\section{Changes during storage of fish sev}

The shelf life study of fish sev was conducted for 90 days at room temperature to check the acceptability of the product based on changes in the proximate composition, biochemical quality indices and sensory quality parameters

\section{Proximate composition}

\section{Changes in moisture content}

The changes in moisture content of fish sev are depicted in Figure 1 (a). From the figure, it can be seen that the moisture content of fish sev increased gradually from $1.89 \%$ to $4.74 \%$ during 90 days of storage period at room temperature. The gradual increase in the 
product may be due to variation in atmospheric relative humidity of the packed material and outside relative humidity which might have resulted in the absorption of moisture from the surrounding. The results in the present investigation are in agreement with some of the reports where in the similar increase in moisture content of the snacks products were observed. Yu et al., 1981; King, 2002; Nurul et al., 2009, 2010 and Neiva et al., 2010 were also observed the great variations in moisture content in the deep fried snacks prepared from rice flour and Colocasia Sevian stored at room temperaturefor60 days. Similar increase in moisture content was also observed by Kaur and Aggarwal, 2015 in potato rice based chakli and Waghray and Gulla (2010) in fried Sev and Boondi. Hina et al., (2017) also observed gradual increase in the moisture content of fish chakli when stored at room temperature for 90 days.

\section{Changes in protein content}

The changes in protein content of fish sev during 90 days storage at room temperature is shown in Figure 1(b). From the results, it was observed that the protein content was decreased from $13.89 \%$ to $13.37 \%$. This reduction in protein content might be due to increase in moisture content and some protein also degraded due to oxidation. These results are in agreement with Agbemafle et al., (2014) who reported decrease in protein content of cream-skinned sweet potato during storage. The gradual decrease in protein content of fish chakli was also observed by Hina et al., (2017) during 90 days storage at room temperature.

\section{Changes in fat content}

The fat content of fish sev reduced insignificantly from initial value of $24.58 \%$ to $24.39 \%$ at the end of 90 days storage at room temperature (Fig. 1c). These slight variations may be due to the fat absorbed by the $\mathrm{Sev}$ during frying and factors such as type of raw material, fish species and inclusion levels of the ingredients (Nural et al., 2010). Agbemafle et al., (2014) also observed the similar values for fat content. The slight reduction in the fat content of the product in the present investigation might also be attributed to the oxidation of fat during storage which also correlates very well with the increase in PV and TBA value of the product in the present investigation. The insignificant reduction in fat content was also observed by Hina et al., (2017) during 90 days storage of fish chakli at room temperature.

\section{Changes in ash content}

The ash content of the fish sev, which mostly represents the presence of minerals and vitamins was analyzed during 90 days storage and the results are depicted in Figure 1(d). The initial value of ash content in the product was $3.40 \%$ which was decreased to $2.84 \%$ at the end of 90 days storage. The ash content of the fried $\mathrm{Sev}$ is similar to those found in other types of fish snack (Siaw et al., 1985; Yu et al., 1994; King, 2002; Nural et al., 2010; Neiva et al., 2011 and Netto and Filho, 2014). Hina et al., (2017) also observed the reduction in ash content of fish chakli during storage at room temperature.

\section{Changes in carbohydrate content}

Among all the constituent reported in sev, carbohydrate content was higher $(57.59 \%)$ in the product and this may be attributed to the addition of almost $50 \%$ starch based material i.e. rice flour and Bengal gram flour in to the product. From the results, it was observed that the carbohydrate content decreased gradually from initial values of $57.59 \%$ to $55.70 \%$ during 90 days of storage at room temperature. This might be attributed to increase in moisture content of $\mathrm{Sev}$. 
Table.1 Standardised recipe of fish Sev

\begin{tabular}{|c|l|c|}
\hline S. No. & \multicolumn{1}{|c|}{ Ingredients } & Quantity \\
\hline 1. & Fish meat (boiled) & $1000 \mathrm{~g}$ \\
\hline 2. & Rice flour & $500 \mathrm{~g}$ \\
\hline 3. & Bengal gram flour & $500 \mathrm{~g}$ \\
\hline 4. & Red chilli powder & $25 \mathrm{~g}$ \\
\hline 5. & Sodium bicarbonate & $10 \mathrm{~g}$ \\
\hline 6. & Salt & $26 \mathrm{~g}$ \\
\hline 7. & Oil & 1 lit \\
\hline
\end{tabular}

Plate.1 Fish Sev from Pangasisus mince

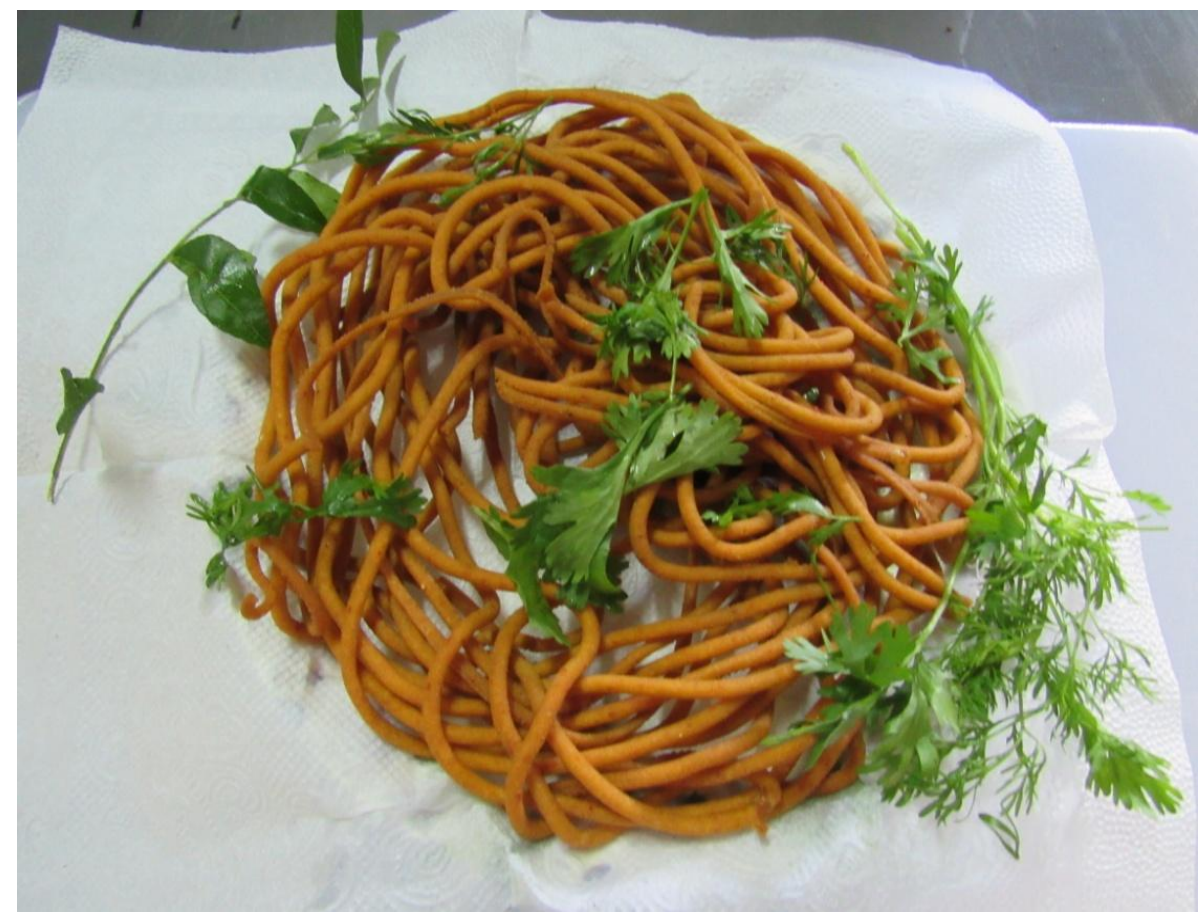

Fig.1 (a, b, c and d) showing proximate composition of $\mathrm{Sev}$

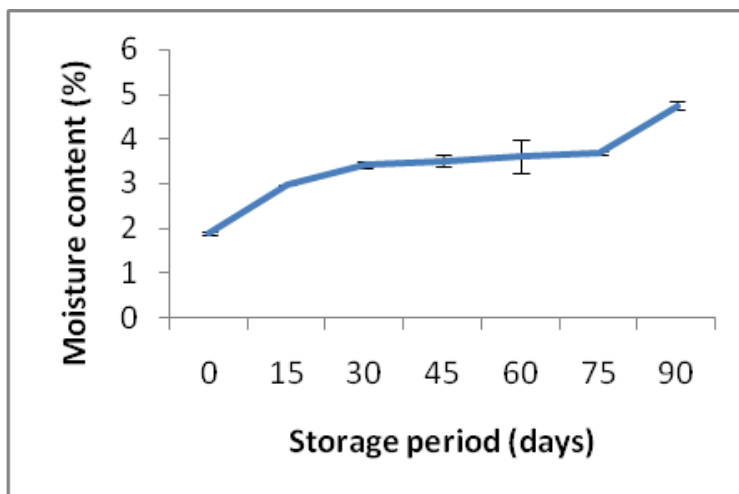

1(a)

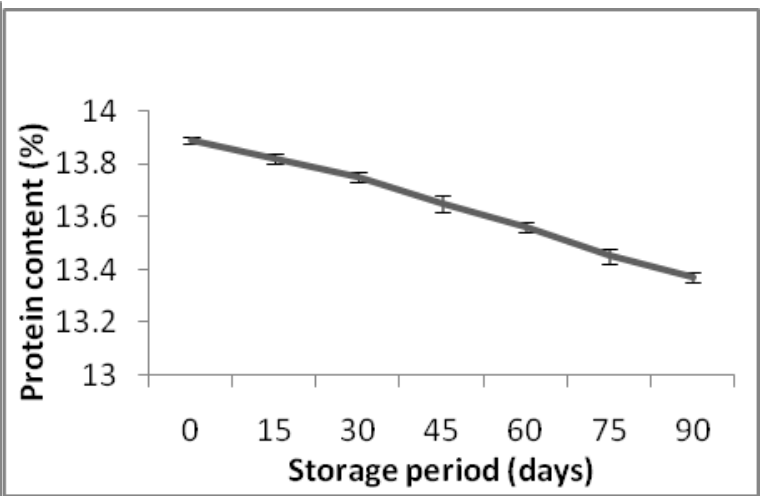

1(b) 


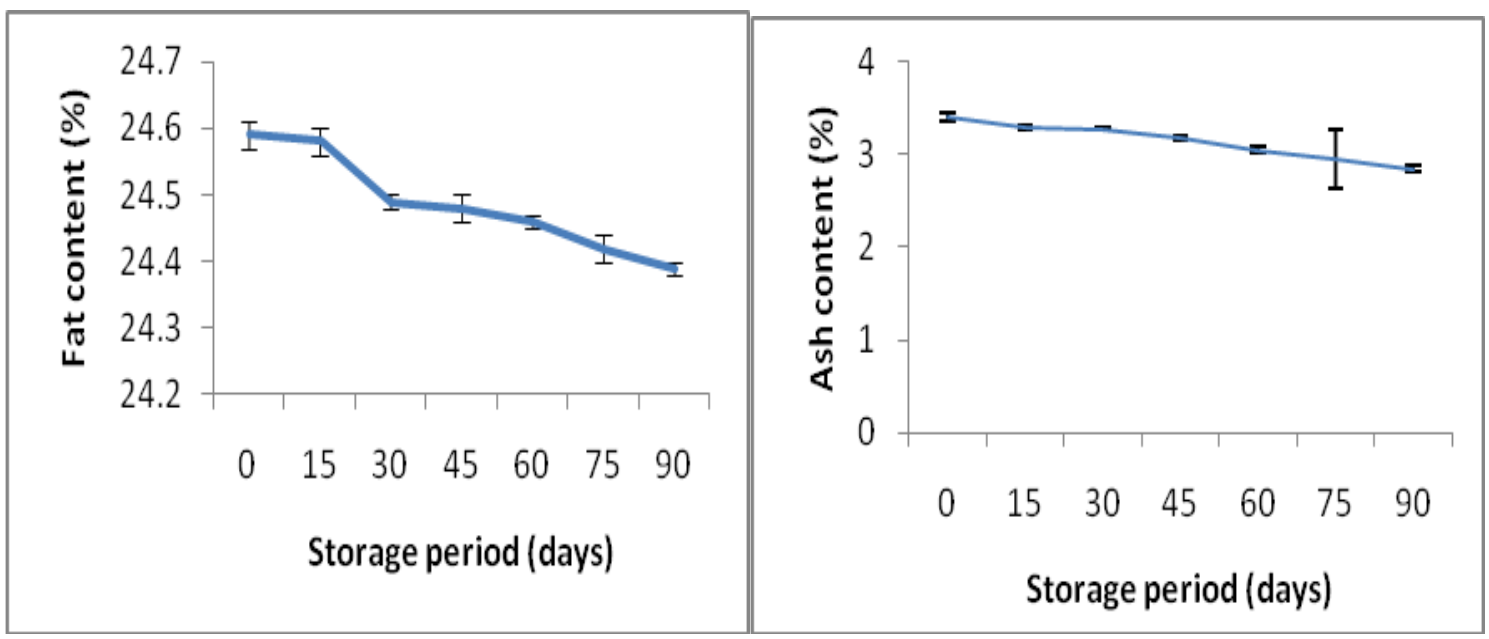

1(c)

1(d)

Bars represent standard deviation of means $(n=3)$

Fig.2 (a, b and c) Biochemical parameters of Sev

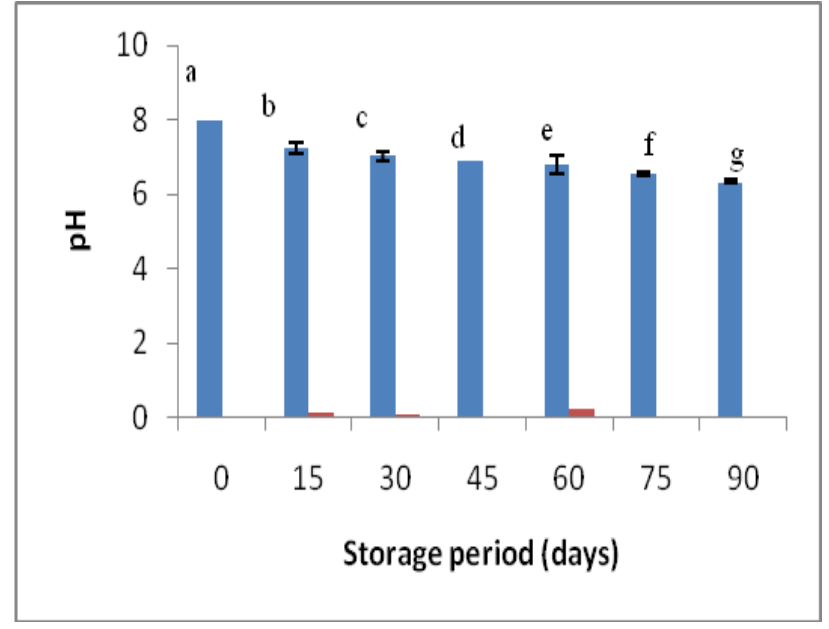

2(a)

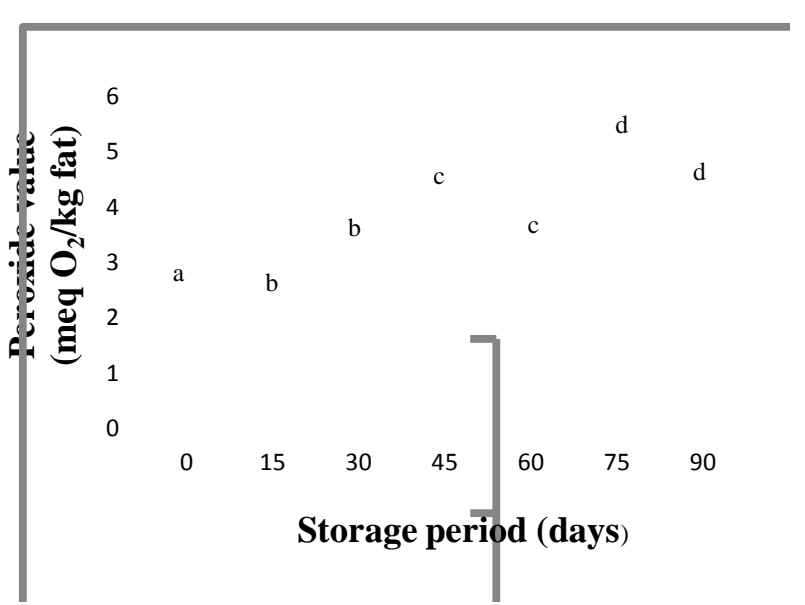

2(b)

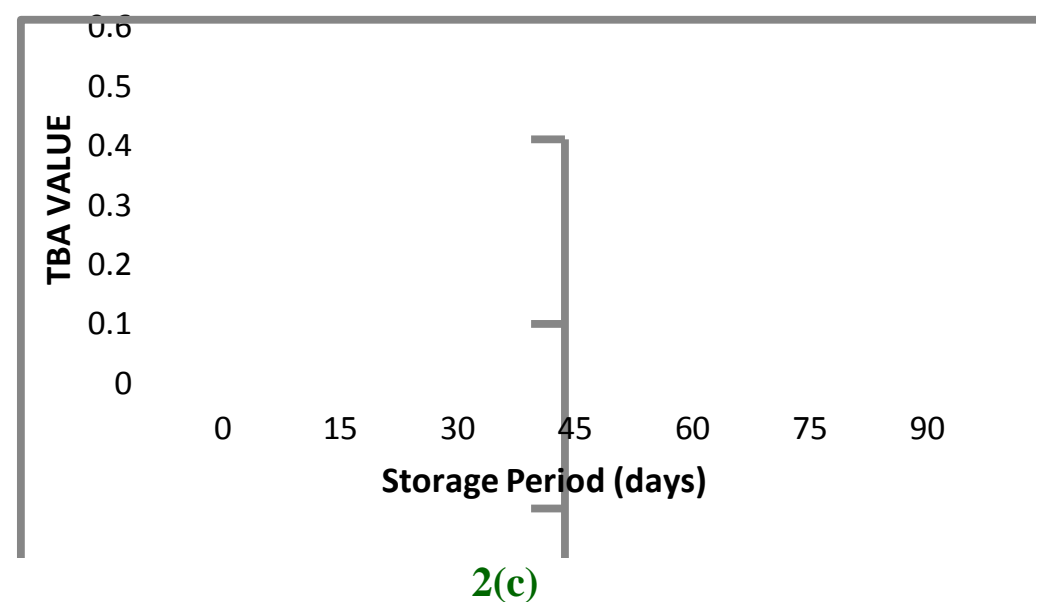

Bars represent standard deviation of means $(n=3)$ 
Fig.3 (a, b, c, d, e and f) Sensorial quality evaluation of $\mathrm{Sev}$

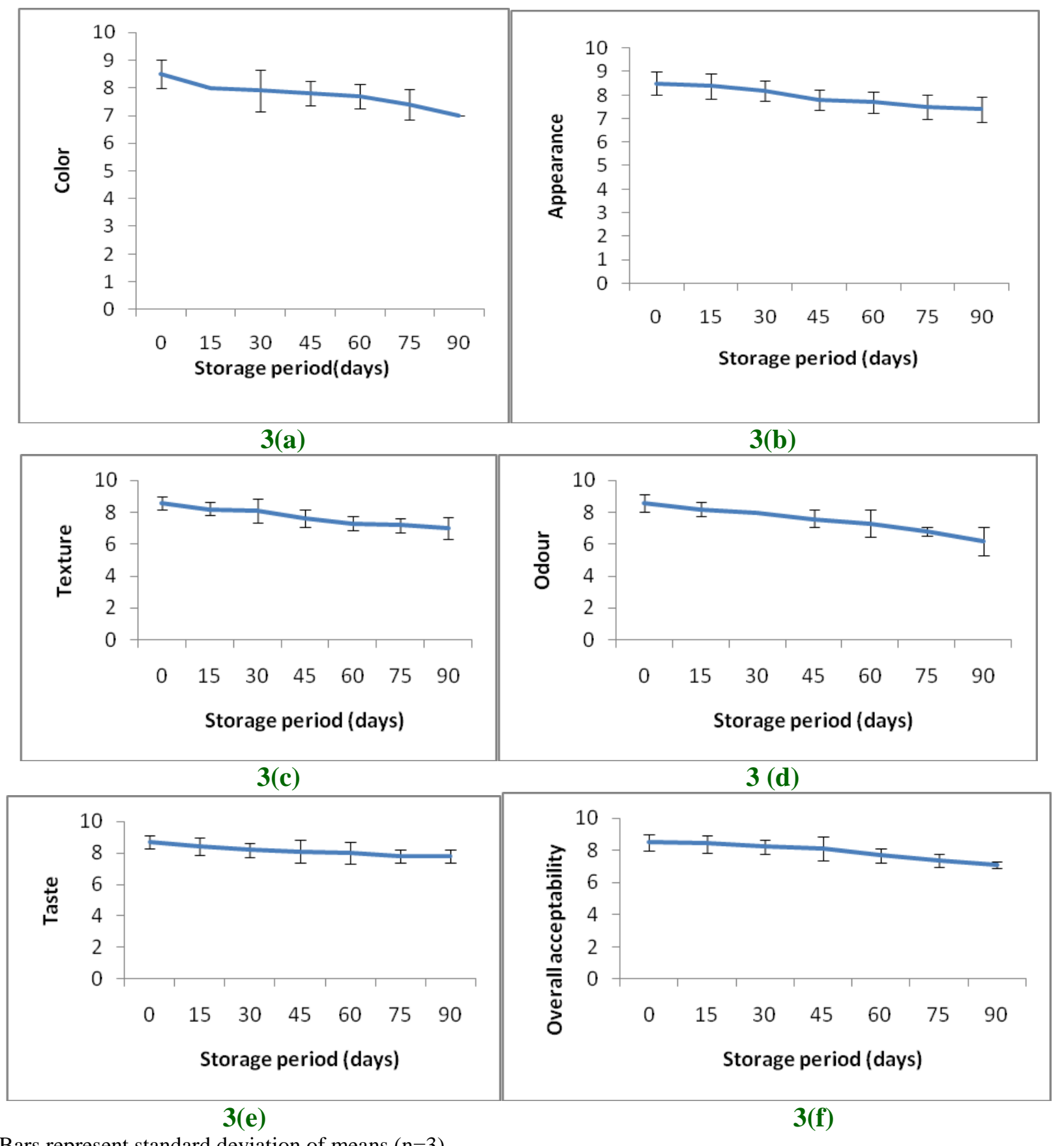

Bars represent standard deviation of means $(n=3)$

Similar results were obtained by Agbemafle et al., (2014) and Hina et al., (2017).

\section{Changes in quality indices}

The products get spoiled mainly due to enzymatic and bacterial activity on the major constituents of the product i.e. protein, fat and carbohydrate which results in the breakdown of those constituent to free fatty acids or bases. This leads to formation of off colour and odour to the product. The oxidation of the fat results in the formation of peroxides and aldehydes which give the rancid smell to the 
product. The quality indices like $\mathrm{pH}, \mathrm{PV}$ and TBARS values of the products were checked during 90 days of storage study at room temperature.

\section{Changes in $\mathrm{pH}$ value}

The changes in the $\mathrm{pH}$ value of the fish sev were recorded and shown in Figure 2(a). From the figure it can be seen that the $\mathrm{pH}$ of the product decreased gradually from an initial value of 7.23 to 6.63 at the end of 90 days storage period.

This decrease in $\mathrm{pH}$ can be attributed to the formation of free fatty acids by the lipolytic enzymes. It is an established fact that a decrease in $\mathrm{pH}$ is usually attributed to the metabolic activity of bacteria (Jay, 1996). Breakdown of carbohydrate by bacteria results in the formation of lactic acid leading to reduce the $\mathrm{pH}$ (Incze, 1992). Hina et al., (2017) also reported gradual reduction in the $\mathrm{pH}$ of fish chakli during 90 days storage at room temperature.

\section{Changes in Peroxide values (PV)}

Changes in Peroxide values during 90 days storage of fish sev are shown in Figure 2(b). The values for PV increased significantly $(\mathrm{P}<0.05)$ throughout the storage and reached to $5.08 \mathrm{meqO}_{2} / \mathrm{kg}$ fat on $90^{\text {th }}$ day of storage from initial value of $2.05 \mathrm{meqO}_{2} / \mathrm{kg}$ fat. Fish sev contained high fat $(24.58 \%)$ and the oxidation of that fat might have resulted in increased PV in the present investigation. Kulkarni et al., (1994) reported an increased PV in stored bhujia prepared from different cereal legume mixtures. Similar observations of increased PV were reported by Berry et al., (1986) in deep fried potato snacks and by Kaur and Aggarwal (2015) for fried Potato rice based sev. Hina et al., (2017) also reported increased PV in fish chakli during 90 days storage period.

\section{Changes Thiobarbituric Acid (TBA)}

The changes in TBA values of fish sev during 90 days storage period is mentioned in Figure 2(c). From the results it is evident that the TBA values for fish sev was increased gradually form 0.15 to 0.51 . The malonadldehydes are formed as end products of secondary oxidation reaction of lipids and the same reacts with the TBA reagent indicating the formation of aldehydes. Aubourg and Medina (1999) has reported that unstable primary oxidation products i.e. hydroperoxides are decomposed rapidly into secondary oxidation products such as aldehydes and ketones. The results obtained in the present investigation are in agreement with the findings of Nikoo et al., (2010) and Zakipour and Baker (2011). However, the values of TBA were within the acceptable limits at the end of 90 days storage.

\section{Sensory quality evaluation}

The fish sev was served to the trained panelist at regular intervals up to 90 days of storage and the changes in the panelists scores for various sensory attributes i.e. color, appearance, texture, odour, taste and overall acceptability of products are given in Figures $3 \mathrm{a}, 3 \mathrm{~b}, 3 \mathrm{c}, 3 \mathrm{~d}, 3 \mathrm{e}$ and $3 \mathrm{f}$ respectively. It was observed from the figures that there was continuous decrease in all the sensory parameters throughout the storage period of 90 days. The changes in sensory properties of any food products are directly related to the chemical reactions taking place in it due to enzymatic and microbial activity. This is very well correlated with the increased PV and TBARS values of the fish sev in the present investigation. However the scores for all the parameters were within the rejection limit i.e., 4 for fish sev at the end of 90 days.

The product prepared from Pangasius mince i.e. fish sev has got good acceptability by the 
panelists with protein content of $13.89 \%$. The fish mince up to $50 \%$ can be incorporated into this product without affecting its textural properties. This type of snack product can be a good alternative not only for the traditional starch based products available in the market but also it can be an alternative for the proper utilization of Pangasius. This will not only help the Pangasius farmers in India but also will be helpful for the fish processing industries of India.

\section{Acknowledgements}

The authors wish to thank Rajiv Gandhi Science and Technology Commission, Mumbai for funding the project on value added products. The authors also wish to thank Director, ICAR-CIFE, Mumbai for his continuous support and encouragement.

\section{References}

AOAC, 2005. Official Methods of Analysis (18th ed) Association of Official Analytical Chemists, Gaithersburg, Maryland20877-2417, USA. Pp. 270310.

Aubourg, S. P. and Medina, I., 1999. Influence of storage time and temperature on lipid deterioration during cod (Gadusmorhua) and haddock (Melanogram musaeglifunus) frozen storage. J. Sci. Food and Agri., 79, 1943-1948.

Berry, S. K., Kulkarni, S. G., Sehgal, R. C., Sushvir, K. and Kalra, C. L., 1986. Studies on the utilization of post-coldstored potatoes in the preparation of potato-besan-sevian. Indian Food Packer, 40, 42-49.

FAO, 2015. Faostat. Food and Agriculture organization of the United Nations, Rome, Italy

Hassan M. A., Balange A. K., Senapati S. R. and Martin K. A., 2017.Effect of different washing cycles on the quality of Pangasius hypophthalmus surimi. Fish. Technol. 54, 51-59.

Hina, A., Martin Xavier K. A., Gangan S. S. and Balange A. K., 2017. Development of fish chakli from Pangasius mince and its storage study. J. Ind. Fish. Assoc. 44 (1), 01-09.

Incze, K., 1992. Raw fermented and dried meat products. Fleischwirtschaft. 72, 58-62.

Jay, J. M., 1996. Modern food microbiology, $4^{\text {th }}$ edn. CBS Publishers and Distributers, New Delhi, India.

Kaur, S. and Aggarwal, P., 2015. Development and quality characteristics of nutritionally enhanced potato rice based Chakli- An indigenous food snack. The Ecoscan. 9(1\& 2), 349-356.

King, M. A., 2002. Development and sensory acceptability of crackers made from the big-eyefish (Branchy deuterusauritus). Food \& Nutr. Bull., 23(2), 317-340. PMid: 12362597.

Kulkarni, S. G., Manan, J. K. and Shukla, I. C., 1994. Studies on deep- fat-fried Sevian made from rice flour and colocasia. J. Food Sci. Technol., 31, 207-210

Lovell T., 1998. Nutrition and feeding of fish, $2^{\text {nd }}$ ed. Boston, MA: Kluwer Academic Publishers.

Neiva, C. R. P., Machado, T. M., Tomita, R. Y., Furlan, E. F., Lemos Neto, M. J., \&Bastos, D.H. M., 2010. Fish crackers development from minced fish and starch: an innovative approach to a traditional product. Ciência $e$ Tecnologia de Alimentos. 31(4), 973979. http:// dx.doi.org/10.1590/S010120612011000400024

Netto, C. and Filho O., 2014. Physicochemical and sensory characteristics of snack made with minced Nile tilapia. Food Sci. Technol, Campinas, 34 (3), 591-596. 
Nikoo, M., Ghomi, M. R., Zakipour R. E., Benjakul, S. and Javadina, B., 2010. The effect of deep -frying, refrigerated storage and reheating on the fat content, oxidation and fatty acid composition of the fish (Rutilus frisiikutum). Food process. Technol., 1(1), 1-4.

Nurul, H., Boni, I., and Noryati, I., 2009. The effect of different ratios of Dory fish to tapioca flour on the linear expansion, oil absorption, colour and hardness of fish crackers. Int. Food Res. Journal.16, 159-165.

Nurul, H., Leng, L. A., Yee, C. X., and Herpandi, 2010. Chemical composition, colour and linear expansion properties of Malaysian commercial fish cracker (keropok). Asian J. Food and Agro- Ind. 3(5), 473-482

Praveen, G.K.R, Martin Xavier K. A., Nayak, B. B., Sanath Kumar H., Venkateshwarlu, G. and Balange, A. K., 2017.Effect of different drying methods on the quality characteristics of Pangasius hypophthalmus. Int.J.Curr.Microbiol.App. Sci.6 (10), 184-195.

Siaw, C. L., Idrus, A. Z., and Yu, S. Y., 1985.Intermediate technology for fish cracker ('keropok') production. Int. J. Food Sci. Technol. 20(1), 17-21.
Steel, R.G.D. and Torrie, J.H., 1980. Principles and procedure of statistics: a biometrical approach. McGraw-Hill Inc., New York, USA

Tarledgis, B.G., Watts, B.M., Younathan, M.J., Dugan, L., 1960.A distillation method for the qualitative determination of malonaldehyde in rancid food. J. Am. Oil Chem. Soc. 37, 44-47.

Waghray, K. and Gulla, S., 2010. Butylatedhydroxyanisole (BHA) to maximize the oxidative stability of snacks: A case study with sev and boondi. J. Human Ecol. 32, 97-99.

Yu, S. Y., Mitchell, J. R., and Abdullah, A., 1981. Production and acceptability testing of fishcrackers ('keropok') prepared by the extrusion method.Int. J. Food Sci. Technol., 16(1), 51-58.

Yu, S. Y., Yeoh, K. C., and Terushige, M., 1994. Utilization of proteins from fish ball processing wash water in fish crackers ('keropok'). J. Food Process. Preservation. 18(6), 453-459.

Zakipour, R., Ahimabadi, E. and Bakar, J., 2011. Effect of four cooking methods (microwave, grilling, steaming and shallow fat frying) on lipid oxidation and fatty acid composition of Scombermorous commersoni. J. Food Sci. Technol.8 (31), 53-61.

\section{How to cite this article:}

Hina Alim, Shardul Gangan, Quraishi Firdaus Mukhtar and Balange, A.K. 2018. Utilization of Pangasius Mince in the Development of Ready to Eat Snacks and Its Storage Study. Int.J.Curr.Microbiol.App.Sci. 7(10): 2314-2324. doi: https://doi.org/10.20546/ijcmas.2018.710.268 